\title{
Translation Studies: Bengali Flavour Intact in English Translation of Tagore's Chokher Bali
}

\author{
Suman Keswani \\ Department of Languages, DRB Sindhu Mahavidyalaya, Nagpur, Maharashtra, India \\ Corresponding author email: suman.keswani2018@gmail.com
}

\section{ABSTRACT}

Translations can be tedious as it is quite a challenge to retain the originality in the translated version.Translation studies provide ample scope for a large cross-cultural impact.Various works of Rabindranath Tagore in Bengali have been translated into English resulting in global reach and recognition.One of his colossal works Chokher Bali has been translated in English by writer Sukhendu Ray. Through multiple characters Mahendra,Ashalata, Binodini and Rajlakshmi, the writer gives a glimpse of Bengali culture without disturbing the original flavour of the novel. The use of Bengali words in the English version adds a regional charm. This paper aims to study the finer nuances of translation for greater effect. Ray succeeds in highlighting the Bengali culture by incorporating Tagore's thoughts and language.The glossary of Bengali words at the end aids in ease of understanding for the readers and retains the simplicity of the novel.

KEY WORDS: MULTICULTURAL, SANCTITY, CODE-SWITCHING, SCANDALOUS, EXHILARATION.

\section{INTRODUCTION}

English literature has been enriched by numerous translations from other languages. India, a country having diverse cultures stands united by the multicultural confluence that impacts the nation. The popularity of the translated novels and short stories of Rabindranath Tagore,Munshi Premchand, Sarat Chandra Chattopadhyaya, Amrita Pritam and many other writers justify that the national and international readers are attracted to the soul-stirring regional stories. Rabindranath Tagore, an eminent figure in the creative world, became renowned worldwide when his Bengali poems, short stories, dramas and novels were translated in English.

Tagore Great Writer And Poet: Rabindranath Tagore (1877- 1941) wrote innumerable stories, songs, dramas which were later translated into many languages. According to the List of Works by Rabindranath Tagore mentioned in Wikipedia ,some of his Bengali short stories like Bhikarini( The Beggar Girl),Ghater Katha (The Ghat's

Biosc Biotech Res Comm P-ISSN: 0974-6455 E-ISSN: 2321-4007

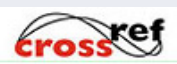

Identifiers and Pagination

Year: 2021 Vol: 14 No (8) Special Issue

Pages: $158-161$

This is an open access article under Creative

Commons License Attribn 4.0 Intl (CC-BY). DOI: http://dx.doi.org/10.21786/bbrc/14.8.36

Story),Byabodhan (The Rift) Khata (Exercise-Book), Ginni (The Housewife),Khokababur Pratyabartan (Return of the Little Master), Postmaster (The Postmaster) , DenaPaonna ( Profit and Loss),Kabuliwallah ( Kabuliwala) and many other were translated in English (web). His novels Bou Thakuranir Haat (The Young Queen's Market ), Ghare Baire (The Home and the World), Rajarshi ( The Royal Sage), Chokher Bali ( A Grain of Sand), Gora (Fair-faced) ,Chaturanga (Chaturanga) could be appreciated by the non-Bengali speaking book-lovers because of the English translations. Also his collections of poems Kabi-Kahani,Bana-Phul,Sandhya Sangeet, Thakurer Padabali,Karo 0 Komal, Manasi, Sonar Tari, Chitra, Chaitali, Kanika, Kalpana,Naivedya,Chayanika, Gitanjali,Utsarga,Balaka, Lekhon, Mahua,Banabani, Shes Saptak, Shyamali,Prantik, Akashdip, Rogshojyay,Shesh Lekha could be relished by poet lovers all over the world because they got translated in English.

Rabindranath Tagore composed a collection of poems Gitanjali in 1910 which was translated in English in 1913. He received the Nobel Prize for it. In one of the translated versions of Gitanjali by Raghukul Tilak published in 2011, Tilak commented in the Preface to the First Edition-" It was with the publication of his English Gitanjali in 1913 that Tagore shot into International fame, and all at once came to be recognised as a great world poet. Since then numerous fresh editions of The Gitanjali have been published and Tagore's song offering has been

Article Information

Received: $08^{\text {th }}$ June 2021 ccepted after revision: $24^{\text {th July }} 2021$ 
translated into most of the important languages of the world." According to Dr Raghukul Tilak mentioned in the above book,such type of literature is termed 'IndoEnglish Literature' which denotes works translated into English from Indian languages. The above term should not be confused with another similar term 'Indo-Anglian Literature' which denotes original English creations by Indians. A third term 'Anglo-Indian Literature' explains the literary creations by Englishmen in the English language about India.

Tagore's Education: Rabindranath Tagore spent his childhood days in Jorasanko,Calcutta amid comfortable care of his progressive family. However he was a lonely child as his parents were too occupied with their own work and so was raised up practically by servants. The course of his education also took him to London where he studied for some time at the University of London under Prof Henry Morley. Later part of his education was mostly self-education from the world of Nature. His poetry My Reminiscences has an autobiographical element describing his childhood days(Tagore,2009).

Ray The Translator: Sukhendu Ray is a renowned name in the field of translation studies. He has translated three novellas of Rabindranath Tagore into English Nashtanir ,Dui Bon,Malancha ( web). Four editions of these novels published between 2010 and 2011 in English are held at renowned libraries worldwide.He has also translated Jibaner Jharapata by Sarala Devi Chaudhurani into English as The Many Worlds of Sarala Devi: A Diary. Also to his credit are English translations of The Betrothed and Bipradas, novels by Sarat Chandra Cattopadhyaya.

Translation An Art: Translations are never easy as the writer has to preserve the regional culture and sanctity of the original work in the new version. To retain the original flavour in the new work becomes a challenge for the translator. It is a tedious task to translate the dialogues of conversation between Indians in English as a lot of code switching has to be used to make it convincing. English has to be reshaped to portray the indigenous culture and the mannerisms of the local people.

Chokher Bali, The Plot: The story of Chokher Bali is set in the 19 th century in the times when widows were considered a burden and widow remarriage was not yet accepted in Bengali society though reforms had been imposed in the legal framework. Chokher Bali is one of the masterpieces of author Rabindranath Tagore (Tagore 2004).The protagonist of the story Binodini is an attractive, seductive widow who has to lead a miserable life for no fault of hers. She is brought by Rajlakshmi,the hero Mahendra's mother, to Calcutta from her village. Mahendra is married to Asha, a simple yet virtuous girl. The newly-wed couple is engrossed in their own marital pleasures when Binodini lands up to break their marital bond.Binodini seduces Mahendra with her charming ways and innate intelligence.In the past Mahindra was about to marry Binodini, but he rejected the proposal without seeing her face. Asha was no match for Binodini, a beautiful, ravishing woman in front of the plain Asha.

Mahendra was besotted with Binodini and began to fantasize and lust for her,ignoring the poor Asha. Asha discovers their clandestine affair through a letter addressed to her husband by Binodini. Her world is turned upside down and she couldn't believe that her best friend Binodini who she calls Chokher Bali could do this to her. Even Bihari Mahendra's dear friend could not make Mahendra understand the gravity of the situation he has created by voicing out his love for Binodini. Mahendra shouts at Bihari,"You suspect that I am in love with Binodini. What absolute rot. I am not in love with Binodini and for heaven's sake you don't have to be my watchdog. On the other hand, I warn you to be on guard... allow me to be outspoken.I accuse you of being in love with Asha (119)."

Rajlaxmi repents her act of sympathy for Binodini and complaints no end for the calamity. She even reprimands her daughter-in-law Asha for being too simple and unattractive. She blames everyone for the course of events including Binodini, Asha, her sister-in-law Annapurna and Mahendra .But she does not realise that it is the fault of her upbringing as she has made Mahendra a spoilt child succumbing to every demand of his. Mahendra uses his manipulative actions to torment the naive Asha. When Asha declares that she wants to go to Kashi to meet her aunt Annapurna,Mahendra is happy that he would be able to spend more time with Binodini. He smiled and said," If you must,you must then.But what will you do if your husband goes astray once you take your eyes off him(130)."His ill-intentions are conveyed through the above lines.Mahendra showered his love on Binodini in the absence of his wife. He poured constant attention on her and waited for her eagerly. When he expressed his love for Binodini she replied," Love is a commodity that I had not been showered with in my life. so why shall I deny any offer of love (147)?”.

The newfound love made Mahendra ecstatic.Tagore weaves the magic of crazy love through his words which Ray translates aptly,"As he strolled on the roof experienced a great sense of exhilaration. That he was found out by Bihari brought a strange sense of liberation. There was an element of ignobility in clandestine affairs. Mahendra had no intention to create a false image of himself as a saint to the outside world (148)." Binodini is the temptress who devastates the marital life of Mahendra and Asha, as she herself could not enjoy the pleasures of married life.Though she plays the role of a vamp, she has multiple shades. She feels guilty and her actions and repents for her misdeeds. Her agony and worry for her future with Mahendra is evident in the following lines," She shuddered at the very thought of the daily strifes that were inevitable between them,in this wretched dark hole that was her home now,

where she lived as a castaway from the society, trying to hold Mahendra at bay. This viper who with its salivating tongue was lasciviously trying to coil its abominable 
body round her was her own creation. And, who can now get rid of it for her (239)." She even tries to seduce Bihari to accept her as his bride.She is hell-bent on obtaining a happy life but is unable to coerce Bihari who is a man of principles. Binodini and Mahendra elope to create their world of happiness but they are unable to do so because of repentance. Binodini longs for Bihari's forgiveness and waits for his company each moment.At last Bihari forgives her and is ready to take her as his wife. But Binodini refuses for marriage as she believes she is unworthy of Bihari and decides to go to Kashi with Annapurna to lead the rest of her life in peace. Binodini was able to visualise her despicable fate if she embraced Mahendra's love.She decides to take her own stand.She is a hardcore feminist and refuses to bow down. She fights against the societal prejudice, her own way by shunning the ill-fated love.She is not ready to be a mistress to Mahendra.

Gender Discrimination: Tagore was able to bring forth the sensitive topic of gender discrimination through this controversial novel. In the Indian patriarchal setup of the 19th century,it was not at all uncommon for men to have extra marital affairs, but for women it was considered a blotch on their chastity. Widows were not allowed to even look in the eyes of men. They were supposed to live a life of oblivion. As rightly said by Michelle Sally in her book The Fallen Angel: Chastity,Class and Women's Reading,"When a woman falls from her purity there is no return for her- as well may one attempt to wash the stain from the sullied snow.Men sin and are forgiven; but the memory of a woman's guilt cannot be removed on earth. Her nature is so exquisitely refined that the slightest flaw becomes a huge defect (Sally,10)." Binodini who dared to be different and wanted to lead a happy existence was ostracized from society. She was turned away by her own aunt,friend, family and relatives as she revolted against the injustice metted out towards widows.In a research article by Nitin Gohad "Gender Discrimination in Mahesh Dattani's Tara in the journal Cenacle,the extent of gender discrimination in Indian society is brought forth through the following lines, "The basic premise of the gender studies is that the civilization is pervasively patriarchal. it is male- centered, controlled and is organised and conducted in such a way as to subordinate women to men in all cultural domains (129).

Literary Devices: Code switching particularly the inter-sentential type is used in the translated version of Chokher Bali by Sukhendu Ray.This takes place within the clause or sentence boundary borrowed from the original language. In a research paper by Dr P.D Nimsarkar in the journal Cenacle, the importance of code mixing and switching to lend an authentic touch is stressed upon." Code mixing and switching is a stylistic device very popular in the literary field, particularly among the creative writers though critics.... During the process of assimilation the code mixed and switched elements are transliterated keeping in view the language to which they belong.In Indian writing in English this trend continues phenomenally (15)."
In Chokher Bali there are various Bengali words used in the English version like Babu,Bouthan,Chaitra, Didi, Ekadashi, Kakima, Koi, Kurta,Mashima, Punkha,Pishima, Sefali, Shehnai, Thakur-po, Topse,etc.Another arduous task for a translator is to convey the author's thoughts and feelings accurately in the translated work. To exhibit love and closeness,Indians shorten their names to form nicknames. This trend is used in the Bengali version and used in the English novel too.Mahendra is shortened to Mohin and Asha to Chuni. A conversation between Mahendra and his aunt Annapurna reveals this.Annapurna answers Mahendra's call,"Oh,is it you Mohin? Come in (5)." Tags are also used in conversation. The Bengali cultural flavour is kept intact through atlength descriptions of Bengali food like Koi fish,Topse fish, paan.Annapurna offers Mahendra a paan through the following words,"But your paan is kept as usual in my room (6)."

Bengali attire like Kurta are used such as," Mother,can you please take out my silk kurta and my fine crimpled dhoti (8)." Names of Bengali months like the name Chaitra as well as Bengali words for calling relatives Mashima,Pishima lend an authentic Bengali flavour and tone to the novel. The glossary of words at the end of the novel alleviates the difficulty of the foreign readers and help them absorb the final nuances of Bengali culture through the meaning of the words. The natural flow of Bengali language is transferred in the English version too as it does not sound alien to the English reader as they can well absorb the culture,ethos and psyche of the Bengali people in this novel.Even the title of the novel is not changed which imparts a rich connect with the Bengali culture.

\section{CONCLUSION}

It can be concluded through the various examples quoted from the translated novel Chokher Bali by Sukhendu Ray that the translator has been able to depict the Bengali culture, traditions and the orthodox social setup in the plot with expertise. By incorporating Bengali words and phrases the authenticity of the original novel has been restored in the English version.It is thereby proved that the translated version does not dilute the strong undercurrents of emotions and feelings as present in the original novel by Rabindranath Tagore. The effective use of code switching techniques like tags and inter and intra-sentential variety could create an ambience of Bengali household and Bengali ethnicity.The novel was also studied through the angles of gender discrimination and feminism.

\section{REFERENCES}

en.m.wikipedia.org/ List of Works of Rabindranath Tagore

Gohad, Nitin, (2011) " Gender Discrimination in Mahesh Dattani's Tara" Cenacle,eds.Shubha Mishra, Urmila Dabir,Oriya Wanjari, Nagpur: Cenacle,Vol 1

Nimsarkar,P.D, (2011) " Code Mixing and Code Switching in Manju Kapur's Difficult Daughters: A Stylistic Study" 
Cenacle,eds.Shubha Mishra, Urmila Dabir,Oriya Wanjari, Nagpur: Cenacle,Vol 1

Sally,Michelle. (1981) The Fallen Angel Chastity, Class and Women's Reading,1835-1888, Bowling Green,OH: Bowling Green State University Popular Press
Tagore, Rabindranath.Chokher Bali.Ray, Sukhendu, translator,New Delhi : Rupa Publications India,2014 Tagore, Rabindranath.My Reminiscences, Book Jungle Tilak, Raghukul.( 2011) Rabindranath Tagore Gitanjali. New Delhi: Rama Brothers India Pvt Ltd 